\title{
Eye injuries in Northern Ireland two years after seat belt legislation
}

\author{
P B JOHNSTON AND M F J ARMSTRONG
}

From the Department of Ophthalmology, Eye and Ear Clinic, Royal Victoria Hospital, Belfast BT12 6BA, Northern Ireland

SUMmaRY Two hundred and forty-six patients with ocular perforation were treated at the Royal Victoria Hospital, Belfast, between 1 February 1981 and 31 January 1985. Road traffic accidents were responsible for 63 injuries, all of which affected front seat occupants, and 45 occurred before implementation of the seat belt law on 1 February 1983. Following legislation there was a $60 \%$ reduction in ocular injuries, which confirms the protective effect on front seat occupants of wearing a seat belt.

Road traffic accidents are a common cause of perforating eye injury with resulting visual loss and cosmetic disability. Johnston' strongly recommended the compulsory use of seat belts to protect car occupants from injury, and evidence from other countries ${ }^{2}$ shows a significant decrease in eye injuries after introduction of seat belt legislation.

The compulsory use of seat belts by front seat occupants of cars was introduced to Great Britain and Northern Ireland on 1 February 1983, and Rutherford $e t$ al. reported a significant reduction in fatalities and injuries from car accidents during the first year after legislation.

We set up a retrospective study which examined the pattern of penetrating eye injuries in Northern Ireland during the two years immediately before and after seat belt wearing became compulsory.

\section{Materials and methods}

The Department of Ophthalmology at the Royal Victoria Hospital, Belfast, is the regional ophthalmic centre for a population of about 1.25 million. We examined the hospital records of all cases of penetrating eye injuries which were treated at the Royal Victoria Hospital from 1 February 1981 to 31 January 1985. Where injury resulted from a road traffic accident, details of the injury, the patient's age and sex, seat belt compliance, position in the vehicle, and visual recovery were recorded.

Correspondence to Mr P B Johnston, FRCS.

\section{Results}

Two hundred and forty-six patients with ocular perforation were treated at the Royal Victoria Hospital between 1 February 1981 and 31 January 1985 (Table 1). A total of 63 injuries were caused by car accidents during the survey, and, of these, 45 cases occurred before and 18 after seat belt legislation, which is a fall of $60 \%\left(\mathrm{p}<0.001, \chi^{2} 11 \cdot 57, \mathrm{df}=1\right)$.

Eight patients (Table 2) sustained injury while wearing a seat belt, and of this group one had a defective belt and another described injury by flying glass when his vehicle was stationary.

Table 1 Distribution of eye injury by cause and year of injury

\begin{tabular}{lrrrrrr}
\hline Cause & \multicolumn{2}{c}{$1981-3$} & & \multicolumn{2}{c}{$1983-5$} \\
\cline { 2 - 3 } \cline { 6 - 7 } & No. & $\%$ & & No. & $\%$ \\
\hline Road traffic accident & 45 & 33.6 & & 18 & 16 \\
Others & 89 & $66 \cdot 4$ & & 94 & 84 \\
Total & 134 & 100 & & 112 & 100 \\
\hline
\end{tabular}

Table 2 Seat belt status of injured patients

\begin{tabular}{lcccccc}
\hline & \multicolumn{2}{c}{$1981-3$} & & \multicolumn{2}{l}{$1983-5$} \\
\cline { 2 - 3 } \cline { 5 - 6 } \cline { 5 - 6 } & No. & $\%$ & & No. & $\%$ \\
\hline Seat belt & 1 & $2 \cdot 2$ & 7 & $38 \cdot 8$ \\
No seat belt & 44 & $97 \cdot 8$ & & 11 & $61 \cdot 2$ \\
Total & 45 & 100 & & 18 & 100 \\
\hline
\end{tabular}


All 63 patients were front seat occupants (Table 3), with no significant difference in the number of front seat passengers and drivers injured. There were no injuries to back seat passengers during the study.

$66 \%$ of injuries affected patients aged $17-29$ years (Table 4 ), and this age range showed a $73 \%$ reduction in ocular perforations sustained after legislation.

Table 5 shows that a greater proportion of patients retained vision of $6 / 6$ in the injured eye in the preseat belt period. During the prelegislation period a greater proportion of patients were rendered totally blind in the injured eye by the accident, and the enucleation rate was greater. A total of six bilateral perforations were treated during the survey, and of

Table 3 Position of injured person in vehicle

\begin{tabular}{lrrrrrr}
\hline & \multicolumn{2}{l}{$1981-3$} & & \multicolumn{2}{l}{$1983-5$} \\
\cline { 2 - 3 } \cline { 5 - 6 } \cline { 5 - 6 } & No. & $\%$ & & No. & $\%$ \\
\hline Driver & 23 & 51 & & 10 & $55 \cdot 5$ \\
Front seat passenger & 22 & 49 & & 8 & $44 \cdot 5$ \\
Total & 45 & 100 & & 18 & 100 \\
\hline
\end{tabular}

Table 4 Distribution of injured patients according to age

\begin{tabular}{lcccccc}
\hline Age when injured (years) & \multicolumn{2}{l}{$1981-3$} & & \multicolumn{2}{l}{$1983-5$} \\
\cline { 2 - 3 } \cline { 6 - 7 } & No. & $\%$ & & No. & $\%$ \\
\hline $0-16$ & 2 & $4 \cdot 4$ & & 3 & $16 \cdot 6$ \\
$17-29$ & 33 & $73 \cdot 3$ & & 9 & $50 \cdot 0$ \\
$30+$ & 10 & $22 \cdot 3$ & & 6 & $33 \cdot 4$ \\
Total & 45 & 100 & & 18 & 100 \\
\hline
\end{tabular}

Table 5 Distribution of eye injuries by final visual acuity

\begin{tabular}{|c|c|c|c|c|}
\hline \multirow[t]{2}{*}{ Acuity } & \multicolumn{2}{|c|}{$1981-3$} & \multicolumn{2}{|c|}{$1983-5$} \\
\hline & No. & $\%$ & No. & $\%$ \\
\hline $6 / 6$ & 15 & $30 \cdot 6 \%$ & 4 & $21 \cdot 0 \%$ \\
\hline $6 / 9-6 / 12$ & 13 & $26 \cdot 5 \%$ & 4 & $21 \cdot 0 \%$ \\
\hline $6 / 18-6 / 36$ & 5 & $10 \cdot 2 \%$ & 5 & $26 \cdot 3 \%$ \\
\hline $6 / 60$ or worse & 4 & $8 \cdot 1 \%$ & 4 & $21 \cdot 0 \%$ \\
\hline No perception of light & 12 & $24 \cdot 5 \%$ & 2 & $10 \cdot 5 \%$ \\
\hline Total & $49^{*}$ & $100 \cdot 0 \%$ & 19 & $100 \cdot 0 \%$ \\
\hline Enucleation & 8 & $16 \cdot 0 \%$ & 1 & $5 \cdot 0 \%$ \\
\hline
\end{tabular}

${ }^{*}$ One patient lost to follow-up.

Table 6 Distribution of injured patients by sex

\begin{tabular}{|c|c|c|}
\hline & $1981-3$ & $1983-5$ \\
\hline & No. \% & No. $\%$ \\
\hline Male & $30 \quad 66 \cdot 6$ & $1372 \cdot 2$ \\
\hline Female & $15 \quad 33.4$ & $\begin{array}{ll}5 & 27 \cdot 8\end{array}$ \\
\hline Total & $45 \quad 100$ & $18 \quad 100$ \\
\hline
\end{tabular}

these only one occurred after the legislation. Males were more susceptible than were females to injury (Table 6).

\section{Discussion}

Road traffic accidents are a major cause of visual loss in the young adult population, and Canavan et al. ${ }^{4}$ found that they caused $30 \cdot 2 \%$ of perforating eye injuries in Northern Ireland from 1967 to 1976. The ocular injury caused by a road traffic accident is usually associated with multiple facial lacerations and may be bilateral. The mechanism of injury comprises impact of the victim's head against a shattered windscreen and perforation caused by flying glass.

Seat belt wearing by front seat occupants of vehicles became compulsory in Northern Ireland on 1 February 1983, and compliance was estimated at $92 \%$ during the first year of legislation compared with $25 \%$ during $1982 .{ }^{3}$ The Royal Victoria Hospital is responsible for the treatment of almost all perforating eye injuries which occur in Northern Ireland. The records of all these injuries were examined during the two years before and after introduction of seat belt legislation. Our survey shows a $60 \%$ reduction in perforating eye injuries following legislation, which corresponds with observations in Wessex, England, by Hall et al., 5 who reported a $73 \%$ reduction in the immediate postlegislation year, and Vernon and Yorston, ${ }^{6}$ who found a $58 \%$ reduction during comparable six-month periods before and after compulsory seat belt use. A multicentre report by Rutherford et al. $^{3}$ showed a decrease by $83.3 \%$ of perforating wounds to the eye in the year after legislation. The significant drop in ocular perforations which followed seat belt legislation in Northern Ireland is not explained by a reduction in road traffic accidents, which increased from 5249 in 1981 to 5978 in $1984 .^{7}$

It is clear that the risk of serious ocular injury by windscreen impact is greatly reduced by seat belt use. However, seat belts do not protect against injury by flying glass. Blake et al. ${ }^{8}$ emphasised the danger of flying windscreen glass as a cause of ocular perforation, and reported that in spite of compulsory seat belt legislation eye injuries in the Republic of Ireland continued to occur at a high rate of 99 injuries in 5182 accidents during 1981. We found an average of nine eye injuries in 5701 accidents following seat belt legislation, and, of these, $39 \%$ were injured while wearing seat belts. Our observations support the view of MacKay" that eye injuries to car occupants could be further reduced if laminated instead of toughened windscreens were used in addition to seat belt use. 
Of those injured before and after legislation the expected level of visual recovery is largely unchanged. Indeed, in the prelegislation period $57 \%$ of our patients regained visual acuity of $6 / 12$ or better compared with $42 \%$ postlegislation. These figures compare with those of Blake ${ }^{x}$ and Canavan et al., who both reported that $44 \%$ of their patients regained $6 / 12$ or better. There was a dramatic decline in the enucleation rate before and after legislation. During 1981-3 eight injured eyes $(16 \%)$ were excised and in $1983-5$ one enucleation $(5 \%)$ was necessary. This compares favourably with enucleation rates of $22.9 \%$ by Blake et al. ${ }^{8}$ and $20.2 \%$ by Canavan et al. ${ }^{*}$ We observed a decline in bilateral ocular perforations during the postlegislation period, which probably reflects the direct effect of legislation in reducing the total number of eye injuries and the protective effect of seat belt use against windscreen impact.

The seat belt legislation introduction to Northern Ireland on 1 February 1983 has effected a remarkable decline in the number of serious eye injuries caused by road traffic accidents. Injuries continue to occur which we believe are due to the non-use of belts, faulty belts, and injury caused by flying glass from toughened windscreens. These injuries may be further reduced by compulsory fitting of laminated windscreens in all newly registered motor vehicles and rigorous enforcement of the seat belt legislation.

\section{References}

1 Johnston SS. Perforating cyc injurics: a five ycar survey. Trans Ophthalmol Soc UK 1971; 91: 895-921.

2 Trinca GW, Dooley BJ. Effects of seat belt legislation on road traffic accidents. Aust NZ J Surg 1977; 47: 675-8.

3 Rutherford WH, Greenficld T, Haycs HRM, Nclson JK. The medical effects of seat belt legislation in the United Kingdom. Department of Health and Social Security Office of the Chicf Scientist. Research report No. 13. London: HMSO, 1985.

4 Canavan YM, O'Flaherty MJ, Archer DB, Elwood JH. A tenyear survey of eye injuries in Northern Ireland 1967-76. Br J Ophthalmol 1980; 64: 618-25.

5 Hall NF, Denning AM, Elkington AR, Cooper PJ. The cyc and the seat belt in Wessex. Br J Ophthalmol 1985; 69: 317-9.

6 Vernon SA, Yorston DB. Incidence of ocular injurics from road traffic accidents after introduction of seat belt legislation. $J R$ Soc Med 1984; 77: 198-200.

7 Royal Ulster Constabulary Traffic Division. Death and Injury Road Accidents in Northern Ireland 1984. HMSO (Northern Ireland): 1984

8 Blake J, Kelly G, Fahcy C, Khan MA. Eyc injurics in road traffic accidents. Ir Med J 1983; 76: 120-4.

9 Blake J. Road blindness. Br Med J 1983; 287: 1718.

10 MacKay GM. Eye injuries and the windscreen. Dublin: Irish Faculty of Ophthalmology, 1975.

Accepted for publication 29 October 1985. 